\title{
Left Spermatic Vein
}

National Cancer Institute

\section{Source}

National Cancer Institute. Left Spermatic Vein. NCI Thesaurus. Code C52696.

A vein that forms the spermatic plexus to drain the left testis into the left renal vein. 